\title{
A Comparison Between Denaturing Gradient Gel Electrophoresis and Denaturing High Performance Liquid Chromatography in Detecting Mutations in Genes Associated with Hereditary Non-Polyposis Colorectal Cancer (HNPCC) and the Identification of 9 New Mutations Previously Unidentified by DGGE
}

\author{
Cliff J. Meldrum', Mary McPhillips', Renee Crooks', Lesley Thomas', Ted Edkins², \\ Rohanna Creegan², Ewan Miller', Michael Agrez ${ }^{3}$, Rodney J. Scott ${ }^{1,4}$
}

'Hunter Area Pathology Service, John Hunter Hospital, New Lambton, NSW 2305, Australia; 2 Princess Margaret Children's Hospital, Perth, Western Australia; ${ }^{3}$ Discipline of Surgical Science, University of Newcastle, NSW 2308 Australia; ${ }^{4}$ Newcastle Bowel Research Collaborative, University of Newcastle and the Hunter Medical Research Institute, Newcastle, NSW Australia

Key words: DGGE, DHPLC, hereditary non-polyposis colorectal cancer mutation detection

Corresponding author: Rodney J. Scott, Discipline of Medical Genetics, Faculty of Health, University of Newcastle, NSW 2308, Austalia. Phone +61 24921 4974,fax+61 24921 4253, e-mail: Rodney.Scott@hunter.health.nsw.gov.au

\begin{abstract}
Denaturing high performance liquid chromatography is a relatively new method by which heteroduplex structures formed during the PCR amplification of heterozygote samples can be rapidly identified. The use of this technology for mutation detection in hereditary non-polyposis colorectal cancer (HNPCC) has the potential to appreciably shorten the time it takes to analyze genes associated with this disorder. Prior to acceptance of this method for screening genes associated with HNPCC, assessment of the reliability of this method should be performed. In this report we have compared mutation and polymorphism detection by denaturing gradient gel electrophoresis (DGGE) with denaturing high performance liquid chromatography (DHPLC) in a set of 130 families. All mutations/polymorphisms representing base substitutions, deletions, insertions and a 23 base pair inversion were detected by DHPLC whereas DGGE failed to identify four single base substitutions and a single base pair deletion. In addition, we show that DHPLC has been used for the identification of 5 different mutations in exon 7 of hMSH2 that could not be detected by DGGE.

From this study we conclude that DHPLC is a more effective and rapid alternative to the detection of mutations in hMSH2 and hMLH1 with the same or better accuracy than DGGE. Furthermore, this technique offers opportunities for automation, which have not been realised for the majority of other methods of gene analysis.
\end{abstract}

\section{Introduction}

HNPCC is an autosomal dominantly inherited disorder that predisposes mutation carriers to an increased risk of early onset colorectal cancer in the absence of any premalignant marker [1]. In addition, mutation carriers are at risk of developing a range of other epithelial cancers, which include endometrial cancer, CNS tumors and cancers of the upper renal tract [2]. The incidence of HNPCC is not accurately known, but is estimated to account for between $1 \%$ and $2 \%$ of all colorectal cancer patients $[3,4]$.

HNPCC is caused by defects in genes that are associated with DNA mismatch repair. DNA mismatch repair is a complex process that involves many genes, four of which have been directly associated with the disease. These genes include hMSH2 on chromosome $2 p[5,6]$, hMLH1 on chromosome 3q [7], hPMS2 on chromosome 2 [8], and hMHS6 on chromosome 7 [9], for a detailed review see Papadopoulos and Lindblom 
[10]. Tumors arising in HNPCC families have a characteristic genetic signature of microsatellite instability (MSI), which can be assayed for by comparing microsatellite DNA profiles from the tumor to profiles from constitutional DNA [1 1, 12].

Two of the four genes account for the majority of HNPCC families, these being hMSH2 and hMLH1 [1316]. Since there are several genes associated with HNPCC the search for inexpensive, rapid detection methods are critical if large scale genetic screening strategies are going to be implemented to offer patients accurate surveillance measures to improve survival.

For a mutation-detection strategy to be effective it must fulfil several requirements. It should have the capacity to be automated, it ought to be inexpensive and it must be accurate. To date most mutation detection strategies do not fulfil all three of these requirements. Most have not been automated or are relatively expensive and none have been assessed properly for their accuracy and this includes direct DNA sequencing, considered to be the "gold standard". There are two mutation detection strategies that are most commonly used for genes involved in HNPCC, these being denaturing gradient gel electrophoresis (DGGE) and single strand conformation polymorphism analysis (SSCP). A third test, the protein truncation test (PTT) is also used for mutation detection in HNPCC, which requires the use of RNA for analysis. Its sensitivity is limited in that it will only identify nonsense mutations and premature stop codons [17]. Other techniques do exist but they are not widely used and suffer from the problem of being technically difficult (examples of which include chemical/enzymatic cleavage mismatch assay and temperature gradient gel electrophoresis) or do not detect a significant majority of mutations.

DHPLC is a new technique that lends itself to automation by virtue of being performed in a column rather than a gel format and providing a rapid, inexpensive and reliable assay. This technique is based on the observation that heteroduplexes will, under partially denaturing conditions, be more likely to denature, compared to their homoduplex counterparts [18]. DHPLC analysis has several advantages compared to other methods of analysis, which include the absence of any radioactive labeling or the purchase of purpose designed oligonucleotides, as is the case with DGGE.

A recent report has compared DHPLC with single strand conformation polymorphism (SSCP) analysis and two dimensional gene scanning (TDGE) analysis and direct sequencing. The results of this comparison indicate that DHPLC is very similar to direct sequencing in terms of sensitivity [19]. No comparison has been reported between DHPLC and DGGE analysis.
In this report we compare and contrast mutation detection using DGGE with that of DHPLC using 95 families that have previously been screened by DGGE analysis revealing 34 changes [20]. A further 30 families were also included in the study as they had subsequently been shown to harbor changes in $\mathrm{hMSH} 2$ or hMLH1. Together the results indicate that DHPLC is a much more accurate screening assay for the analysis of genes associated with HNPCC and it can be performed much more rapidly.

\section{Materials and methods}

A total of 130 unrelated patients were screened for mutations and polymorphisms in hMLH1 and hMSH2 using DGGE and DHPLC. The diagnosis of HNPCC was made on the basis that all patients had family histories consistent with the Amsterdam criteria [21]. All patients provided informed consent for genetic studies after appropriate genetic counseling for HNPCC.

Genomic DNA was isolated from EDTA blood according to the method described by Miller et al. [22]. Briefly, blood samples were mixed with erythrocyte lysis (EL) buffer (155 mM NH${ }_{4} \mathrm{Cl}, 10 \mathrm{mM} \mathrm{KHCO}_{3}, 1 \mathrm{mM}$ EDTA, pH 7.4). The lysate was centrifuged, washed twice with EL buffer, and the intact lymphocyte pellet resuspended in nuclei lysis (NL) buffer $(2 \mathrm{ml} ; 100 \mathrm{mM}$ TRIS-Cl, pH 8.0, 100 mM NaCl, 2 mM Na2EDTA, 1\% SDS and $1 \mathrm{mg} / \mathrm{ml}$ proteinase $\mathrm{K}$, and incubated overnight at $55^{\circ} \mathrm{C}$. The next day, $333 \mathrm{ul} / \mathrm{ml}$ of sample of $6 \mathrm{M} \mathrm{NaCl}$ was added, mixed and centrifuged to remove cellular proteins from the solution. The supernatant containing the DNA was placed in a fresh tube and the DNA precipitated with ethanol. The resulting DNA pellet was washed with $70 \%$ ethanol, dried briefly and then reconstituted in TE buffer (10 $\mathrm{mM}$ TRIS-Cl, $\mathrm{pH}$ 8.0, 1 $\mathrm{mM}$ EDTA) to a concentration of $500 \mathrm{ng} / \mathrm{ul}$.

\section{DGGE Analysis}

DGGE analysis was essentially performed according to the methods of Wijnen et al. [23, 24]. Briefly, PCR amplification was performed using 250 to 500 ng of genomic DNA, $1 \cup$ Taq polymerase (Boeringher/Mannheim), $200 \mu \mathrm{M}$ each nucleotide, 4 to $10 \%$ glycerol, $10 \mathrm{mM}$ Tris- $\mathrm{Cl}(\mathrm{pH} 9.0), 1.0-5.0 \mathrm{mM}$ $\mathrm{MgCl}_{2}$ and $1.0 \mu \mathrm{M}$ concentrations of the appropriate forward and reverse primers. A GC clamp was incorporated at the $5^{\prime}$ end of one primer of each pair for DGGE analysed as described previously Wijnen et al $[23,24]$. The primer sequences for each exon of hMSH2 and hMLH1 were exactly as described. PCR amplification was achieved by an initial denaturation 
at $94^{\circ} \mathrm{C}$ for $5 \mathrm{~min}$ followed by 35 cycles of $94^{\circ} \mathrm{C}$ for 1 $\min , 55$ to $58^{\circ} \mathrm{C}$ for $1.5 \mathrm{~min}$ and $72^{\circ} \mathrm{C}$ for 2 min then a final extension step at $72^{\circ} \mathrm{C}$ for $10 \mathrm{~min}$. DGGE was performed by separating 5 to $15 \mu \mathrm{l}$ of PCR product mixed with an equal volume of gel loading buffer (15\% Ficol1, 0.25\% Bromophenol Blue, 0.25\% Xylene Cyanol) on a $10 \%$ polyacrylamide gel that contained a denaturing gradient $1100 \%$ denaturant is $40 \%$ formamide, $42 \% \mathrm{w} / \mathrm{v}$ urea) suitable for each exon being analysed (see Table 1 for exon specific gradients). The gel and electrophoresis buffer were both TAE (40 $\mathrm{mM}$ Tris acetate $\mathrm{pH} 7.5,1 \mathrm{mM}$ EDTA). DGGE separation was performed overnight for 16 hours at $60^{\circ} \mathrm{C}$ and $40 \mathrm{~V}$ and visualized by ethidium bromide staining, UV transillumination and photography.

\section{DHPLC Analysis}

PCR amplification for DHPLC analysis was performed using primers previously designed for SSCP analysis of both hMLH1 and hMSH2 (see Table 2) with minor modification. The reaction consisted of $1.0 \mu \mathrm{M}$ each primer, $1 \cup$ Platinum Taq (Gibco-BRL), 2-5 mM $\mathrm{MgCl} 2$ and $200 \mu \mathrm{M}$ each dNTP.

PCR amplification was achieved by an initial denaturation at $94^{\circ} \mathrm{C}$ for 5 min followed by 14 cycles of $94^{\circ} \mathrm{C}$ for $1 \mathrm{~min}, 7^{\circ} \mathrm{C}$ touchdown range for $1.5 \mathrm{~min}$ and $72^{\circ} \mathrm{C}$ for 2 min then 20 cycles using an annealing temperature $0.5^{\circ} \mathrm{C}$ lower than the bottom of the touchdown range. The annealing step was performed as a touchdown protocol with a $7^{\circ} \mathrm{C}$ range, decreasing $0.5^{\circ} \mathrm{C} /$ cycle over 14 cycles. This was followed by a final extension step at $72^{\circ} \mathrm{C}$ for $10 \mathrm{~min}$, a final denaturation step at $95^{\circ} \mathrm{C}$ for $5 \mathrm{~min}$ and a slow annealing step from $95^{\circ} \mathrm{C}$ to $65^{\circ} \mathrm{C}$ over $30 \mathrm{~min}$ to promote heteroduplex formation. The PCR was performed on a PCR express (Hybaid) instrument equipped with a heated lid to avoid the use of mineral oil.

DHPLC analysis was performed using a Varian Helix system (Varian Inc., Walnut Creek, CA). PCR products $(2-5 \mu l)$ were injected directly into a DNA Eclipse (Hewlett Packard) or Helix (Varian) column and eluted from the column using an increasing acetonitrile gradient and a column oven temperature suitable for each exon of hMLH1 and hMSH2 (see Table 3). Heteroduplexes formed during PCR of a heterozygote sample were detected as an additional peak eluting before the homoduplex peak. The detection of heteroduplexes was made simpler with the use of DHPLC review software supplied from Varian. The predicted melting temperatures of the double stranded DNA products were obtained by using the DHPLC-MELT program available from http://www.insertion.stanford.edu/melt.html.
For each segment a negative control fragment (amplified from DNA isolated from a normal healthy donor who had no family history of disease) was run through the denaturing column at the non-denaturing temperature of $50^{\circ} \mathrm{C}$. The $50^{\circ} \mathrm{C}$ peak profile was then compared to the Stanford melting temperature profile of the respective fragment as well as three $1{ }^{\circ} \mathrm{C}$ increments on either side of predicted melting temperature. Partially denatured conditions were established when a shift in retention time of at least or equal to 30 seconds across a $1^{\circ} \mathrm{C}$ increment range. The optimal melting temperature was always taken as the higher temperature, under partially denaturing conditions that did not exhibit profile degradation.

\section{DNA Sequencing}

All heteroduplexes were subject to DNA sequencing to determine the precise genetic change on a semiautomated sequencing unit (model 310, Perkin-Elmer Applied Biosystems Division, Foster City, CA) using dideoxy sequencing of the PCR products was performed using version 1 BIGDYE dideoxy sequencing Ready Rxn kit (Perkin-Elmer, Foster City, CA).

\section{Results \\ DGGE Analysis}

From a total number of 130 patients 41 genetic differences were identified by DGGE. 15 alterations were found in $\mathrm{hMSH} 2$ and 26 in $\mathrm{hMLH} 1$. All alterations in hMSH2 and hMLH1 were checked against the published sequence (accession number U03911 and U07418, respectively). A brief description of the affected exon in either hMSH2 or hMLH1 is shown in Table 3.

\section{DHPLC Analysis}

All 130 samples that had been subjected to DGGE analysis were tested by DHPLC to determine if this methodology was at least as reliable as DGGE. All DNA fragments analyzed were shorter than 420 base pairs in length. A size limitation of $450 \mathrm{bp}$ was chosen so that the flow rate through the denaturing column and denaturing gradient remained constant. The only parameter that was varied in this analysis was the column temperature. Predicted DNA melting temperatures are shown Table 3. The actual melting temperature of the heteroduplexes varied from the predicted by a maximum of $4^{\circ} \mathrm{C}$ and most heteroduplexes melted at one of the predicted temperatures. A total of 50 changes were observed using DHPLC which included 9 additional 
Table 1. Increasing urea gradients used for DGGE analysis of all exons comprising hMLH1 and hMSH2

\begin{tabular}{|c|c|}
\hline Denaturant Gradient & Gene/Exon \\
\hline $15-30 \%$ & HMSH2 exon 16 \\
\hline $20-50 \%$ & $\mathrm{HMSH} 2$ exon 4 \\
\hline $25-45 \%$ & HMSH2 exons $2,8,12$ \\
\hline $30-40 \%$ & HMSH2 exons 3, 5, 7, 11 \\
\hline $30-45 \%$ & HMSH2 exons 6, 9 \\
\hline $30-50 \%$ & HMSH2 exons 14,15 \\
\hline $35-45 \%$ & $\begin{array}{l}\text { HMSH2 exon } 1, h M L H 1 \text { exons } \\
3,9,15\end{array}$ \\
\hline $38-48 \%$ & hMLHI exon 7 \\
\hline $40-50 \%$ & hMLH1 exons $4,5,6,8,10,16,17$ \\
\hline $40-60 \%$ & hMLH1 exon 18 \\
\hline $40-70 \%$ & hMLH1 exon 11 \\
\hline $42-52 \%$ & hMLH1 exon 19 \\
\hline $45-55 \%$ & $\begin{array}{l}\text { hMSH2 exon } 13, \mathrm{hMLH} 1 \text { exons } \\
2,12,13,14\end{array}$ \\
\hline $50-70 \%$ & hMSH2 exon 1, hMLH1 exon 1 \\
\hline
\end{tabular}

changes that were not detected by DGGE. DHPLC analysis revealed that single base pair changes, deletions or insertions could be readily identified as well as larger base pair changes (for examples see Fig. 1).

A potential difficulty with DHPLC analysis could be the identification of more complex changes such as common polymorphisms that may occur in the proximity of a mutation. The identification of the mutation may be compromised by virtue of the polymorphism. The heteroduplex melting profile of exon 8, hMLH1, which harbors a common polymorphism ( $G$ to $A$ ) at position 655 and a mutation (T deletion) at nucleotide 672 is shown in Fig. 2. Each change gave a distinct and unique profile both individually and in combination.

There were nine additional changes not found by DGGE that were apparent by DHPLC as indicated in Table 3. The changes included a $C$ to $T$ substitution at position +51 upstream of the splice site in exon 6 of $\mathrm{hMLH1}$; a $\mathrm{T}$ to $\mathrm{C}$ substitution at position +6 in exon 13 of hMSH2; and a $\mathrm{G}$ to $A$ substitution at position 884 in exon 10 of hMLH1. All three changes were easily detected by DHPLC (see Fig. 3). Of particular note was the identification of four substitutions and one deletion that were detected in exon 7 of hMSH2, which could not be observed when analysed by DGGE. Interrogation of the sequence of exon $7 \mathrm{did}$ not reveal any unusual melting domains, which could adversely affect the melting temperature in the presence of a GC-clamp.

The analysis of fragments with DNA sequence variations usually result in distinct melting profiles, sometimes however, we observed similar profiles for DNA fragments, harbouring non-identical changes from the wild type allele and to each other, an example is shown in Fig. 4. In this example two different genetic changes, a substitution at position 965 ( $G$ to $A$ ) and another at position 1009 (C to T) in exon 6 of hMSH2 resulted in very similar profiles whereas a $984 \mathrm{C}$ to $\mathrm{T}$ change was distinct.

Finally, DNA melting temperatures and the resulting melt profiles correlate very well when there are small base composition changes (small insertions, deletions and substitutions) but are not so well associated when larger changes are present. It was our observation that some changes were not as stable as others.

\section{DGGE versus DHPLC}

Identification of unusual heteroduplexes by DHPLC appeared to be more accurate than by DGGE (see Table 4) as some of the conformers were undetectable using this methodology. Evidence for this is shown in Fig. 3. In total, we identified in our cohort of samples 9 examples where DGGE failed to detect heteroduplex differences. Conversely, no DNA sequence variations identified by DGGE were undetected by DHPLC.

In total, 50 changes were identified, 50 by DHPLC and 41 by DGGE suggesting that DHPLC is a more accurate method by which mutations can be identified, in HNPCC patients using the described protocol. Within the total sample population, 130 index patients were studied by both DHPLC and DGGE. Using this approach it was impossible to determine if other changes had been missed by either of the two techniques, as direct sequencing was not performed on any of the gene fragments unless a change had been observed.

\section{Discussion}

The analysis of genes associated with the colorectal cancer predisposition HNPCC remains problematic since there are a number of different genes, which predispose to this disorder. In this report we have focused on the two genes (hMSH2 and hMLH1) that account for the majority of families that are consistent with a diagnosis of HNPCC. Several different techniques have been utilized in the identification of genetic differences in hMSH2 and hMLH1, however, in this 
Table 2. Primers used for DHPLC analysis of hMLH1 and hMSH2

\begin{tabular}{|c|c|c|}
\hline hMLHI & Fonward & Reverse \\
\hline Exon 1 & GAA CAT CTA GAC GTT TCC & GTT AAG TCG TAG CCC TTA \\
\hline Exon 2 & CAT TAG AGT AGT TGC AGA CTG & CGC ACA AAC ATC CTG CTA CT \\
\hline Exon 3 & GAG TAA CAT GAT TAT TTA CTC & AAC AGG AGG ATA TTT TAC ACA \\
\hline Exon 4 & CAG TTC AGA TAA GGT TTC C & TAT GAG TAA AAG AAG TCA GCA \\
\hline Exon 5 & СTC TCT ACT GGA TAT TAA TTT G & AAG CTT CAA CAA TTT ACT CTC C \\
\hline Exon 6 & CTA TCT TAA GAC CTC GCT & TAT GAG CAC TAG AAC ACA TT \\
\hline Exon 7 & TCT AGT GTG TGT TTT TGG CA & CAT GGC TGA GAC TGA AAC \\
\hline Exon 8 & AAT AAA TCC TTG TGT CTT CTG & TTT TTA TAT AGG TTA TCG ACA TA \\
\hline Exon 9 & TTA TGC TTC AGA ATC TCT TTT C & TGT TTC CTG TGA GTG GAT \\
\hline Exon 10 & TTT GTG TGA ATG TAC ACC TG & TCT GTT CCT TGT GAG TCT \\
\hline Exon 11 & CTA AGG TAA TTG TTC TCT CTT A & CAG AGA AGT AGC TGG ATG \\
\hline Exon 12 & TAA TAC AGA CTT TGC TAC CAG GA & GGT AGG CTG TAC TTT TCC CA \\
\hline Exon 13 & CTG CAC TTC СTT TTC TTC AT & CCT ATG CAT CCC AGG CA \\
\hline Exon 14 & AGG ATT CTA TTA CTT ACC TG & TCT GCT TGT TCA CAC ACT CA \\
\hline Exon 15 & CAA CTG GTT GTA TCT CAA G & TAC AAA TAA GAT ATT AGT GGA GA \\
\hline Exon 16 & CTT GGG AAT TCA GGC TTC & AGA AGT ATA AGA ATG GCT GTC A \\
\hline Exon 17 & CAG CAT TAT TTC TTG TTC CC & CAC ATG CAT GTA CCG AAA \\
\hline Exon 18 & ATT CGT ACC TAT TTT GAG GT & TTG TAT AGG CCT GTC CTA \\
\hline Exon 19 & AGC CAG GAC ACC AGT GTA & GAA CAC ATC CCA CAG TGC \\
\hline hMSH2 & Fonward & Reverse \\
\hline Exon 1 & CTT CAA CCA GGA GGT GAG & AAA GGA GCC GCG CCA \\
\hline Exon 2 & CAG CTA ATA CAG TGC TTG & GTA AAT TAA AAA GGA AGA TAA TTA C \\
\hline Exon 3 & GCT TAT AAA ATT TTA AAG TAT GTT C & GCC TTT CCT AGG CCT GGA ATC TCC \\
\hline Exon 4 & TTC ATT TTT GCT TTT CTT ATT CC & ATA TGA CAG AAA TAT CCT TC \\
\hline Exon 5 & CAG TGG TAT AGA AAT CTT CG & CCA ATC AAC ATT TTT AAC CC \\
\hline Exon 6 & GTT TTC ACT AAT GAG CTT GCC & ATG TGG GTA ACT GCA GGT TAC \\
\hline Exon 7 & GAC TTA CGT GCT TAG TTG & GTA TAT ATT GTA TGA GTT GAA GG \\
\hline Exon 8 & TTG TAT TCT GTA AAA TGA GAT C & GCT TTT TAA AAA TAA CTA CTG C \\
\hline Exon 9 & GGA TTT TGT CAC TTT GTT CTG & ATT ATT CCA ACC TCC AAT GAC \\
\hline Exon 10 & GGT AGT AGG TAT TTA TGG AA & CAT TTA GGG AAT TAA TAA AGG G \\
\hline Exon 11 & CAC ATT GCT TCT AGT ACA C & CCA GGT GAC ATT CAG AAC \\
\hline Exon 12 & ATT CAG TAT TCC TGT GTA CA & CCA CAA AGC CCA AAA ACC A \\
\hline Exon 13 & CAA TCC ATT TAT TAG TAG CAG & TTC TAT CTT CAA GGG ACT AG \\
\hline Exon 14 & TAC CAC ATT TTA TGT GAT GGG & TAC CAA GTT CTG AAT TTA GAG \\
\hline Exon 15 & TTC TCA TGC TGT CCC CTC A & AGA GAA GCT AAG TTA AAC TAT G \\
\hline Exon 16 & TAA TTA CTC ATG GGA CAT TCA C & TAC CTT CAT TCC ATT ACT GG \\
\hline
\end{tabular}


report we concentrated on comparing DGGE with DHPLC analysis as there are several reports suggesting that it is a superior mutation detection technique after direct sequencing, see Ziao and Oefner [25]. The only significant study to evaluate a number of different mutation detection strategies and DHPLC focused on single strand conformation polymorphism analysis (SSCP), conformation sensitive gel electrophoresis (CSGE) and two dimensional gene scanning (TDGS). The results of this study indicate that DHPLC is as sensitive as direct sequencing [19]. In the current study an evaluation between DHPLC and DGGE has been performed which further confirms the superior nature of DHPLC against many other mutation detection methods except perhaps direct sequencing.

In this study we have investigated a series of families that were diagnosed by virtue of the fact that they adhered to the Amsterdam criteria [21]. There are other criteria that could have been used but for this comparative analysis it was considered more meaningful to test a minimum set of similar families, which could be easily compared.

Using the conditions described by Wijnen et al. [23, 24] we have found that DGGE analysis for mutation detection is relatively rapid and accurate. A series of changes were identified by this technique, which included single base pair substitutions, deletions and insertions, as well as larger genetic alterations [20]. DHPLC on the other hand appears to be a more accurate method of analysis since 9 additional mutations were identified using this technique, which could not be detected by DGGE analysis. Since we did not compare direct sequencing with DHPLC analysis it is impossible to determine the relative sensitivity of DHPLC, however, a recent report suggests that the detection rate is very similar [19]. Of particular interest was the finding of 5 different and distinct mutations in exon 7 of hMSH2, which were not identified by DGGE analysis. Examination of the predicted melting temperatures does not suggest significantly different melting temperatures in most domains except in the region immediately adjacent to the GC-clamp, which may interfere with the structure of the heteroduplex. This may influence the role of the GC-clamp for DGGE analysis, which is not present for DHPLC analysis.

In comparing the two techniques there are advantages and disadvantages of both methods. The primary disadvantage of DGGE is the initial time required to establish the appropriate melting conditions to achieve optimal separation of mutant alleles. This requires the use of 2-D gradient gels and knowledge about the predicted DNA melting temperature. Several programs have been developed to predict DNA melting temperatures and most use the MELT 87 program developed by in 1987 [26]. DHPLC as opposed to DGGE does not require extensive 2-D gradient gel electrophoresis but knowledge about the predicted DNA melting temperature is required. The predicted melting temperature proved very useful in determining the correct temperatures for small changes such as single base pair substitutions, insertions or deletions. When larger changes were analyzed at higher temperatures there was a slight loss of predictive accuracy, which was most likely due to the instability of the particular heteroduplex and its consequent breakdown. In contrast to single nucleotide polymorphism (SNP) analysis by DHPLC, mutation screening by DHPLC should include analysis at lower than predicted or even non-denaturing temperatures to detect larger sequence changes. This would increase the sensitivity of mutation detection by DHPLC. All temperatures that were predicted were within four degrees of the actual temperature. In summary, the predictive power of the algorithm proved to be essential for rapid analysis and compared with DGGE optimization of the conditions for DHPLC also proved to be particularly advantageous. The speed at which DHPLC analysis is performed allowed the accurate identification of melting temperature within 30 minutes of analysis. The analysis of DNA fragments at different temperatures for mutation detection must be exhaustively analyzed compared to other applications for DHPLC. An important difference between mutation detection and for instance SNP analysis (where rapid throughput is required) is the extent to which melting temperatures are interrogated. Using DHPLC for SNP identification may have limitations as some SNPs will not necessarily be identified unless a range of temperatures are tested on each segment of DNA under investigation.

Elution profiles appear to be consistent between fragments of DNA that harbor the same change when analyzed during one run of the system. Unique elution profiles were found to generally occur for different mutations offering the possibility of unique "family mutation" profile analysis by DHPLC. We cannot recommend this since some mutations due to different base pair changes did result in elution profiles that were almost identical. Taken together, we considered that DHPLC is not an appropriate substitute for DNA sequencing.

In comparison to DGGE, DHPLC represents a relatively cost effective alternative. If capital costs are ignored for DGGE and DHPLC, the running cost of DHPLC is approximately 90 US cents per sample with a throughput rate of approximately 5 minutes per sample. DGGE is less expensive to perform with respect to consumable costs but requires post-resolution manipulation to visualize the results, which effectively 
Table 3. Mutations identified by DHPLC with the predicted and actual temperatures of detection and a summary of which mutations were identified by DGGE

\begin{tabular}{|c|c|c|c|c|c|}
\hline Gene/Exon & Mutation Description & $\begin{array}{l}\text { Fragment Size } \\
\text { (bp) }\end{array}$ & $\begin{array}{c}\text { Predicted } \\
\text { Temperature }\end{array}$ & $\begin{array}{c}\text { Actual } \\
\text { Temperature } \\
\text { Detected }\end{array}$ & $\begin{array}{c}\text { Detected by } \\
\text { DGGE/DHPLC }\end{array}$ \\
\hline \multicolumn{6}{|l|}{ hMLH1 } \\
\hline 1 & G to $A(116)$ splice site & 200 & 62 & 60 & $y / y$ \\
\hline 1 & A to $G(1)$ & 200 & 62 & 60 & $y / y$ \\
\hline 1 & A to $G(112)$ & 200 & 62 & 60 & $y / y$ \\
\hline 4 & $C$ to $T(350)$ & 191 & 54,59 & 59 & $y / y$ \\
\hline 4 & $G$ to $A(+1)$ & 191 & 54,59 & 54 & $y / y$ \\
\hline 6 & $C$ to $T(+51)$ & 230 & 56 & 56 & $y / y$ \\
\hline 7 & $T$ to $G(554)$ & 205 & 55 & 58 & $y / y$ \\
\hline 8 & A to $G(655)$ & 149 & $48,53,55,58$ & 58 & $y / y$ \\
\hline 9 & A to $G(790)$ splice site & 181 & 56 & 58 & $y / y$ \\
\hline 10 & $G$ to $A(884)$ & 213 & 58 & 58 & $n / y$ \\
\hline 13 & $G$ to $A(+13)$ & 209 & 59 & $57,58,59$ & $y / y$ \\
\hline 13 & $G$ to $T(1535)$ & 209 & 59 & 58,59 & $y / y$ \\
\hline 15 & G to $A(1731)$ splice site & 210 & 49,54 & 54 & $y / y$ \\
\hline 16 & AA to GC (1852-3) & 259 & 55,60 & 55,60 & $y / y$ \\
\hline 17 & G to $T$ (1959) & 178 & 59 & 58,59 & $y / y$ \\
\hline 17 & G to A (1989) splice site & 178 & 59 & $57,58,59$ & $y / y$ \\
\hline 19 & $A$ to $G(2253)$ & 266 & 59 & 56,57 & $y / y$ \\
\hline 19 & G to $A(2147)$ & 266 & 59 & 58,59 & $y / y$ \\
\hline \multicolumn{6}{|l|}{ hMSH2 } \\
\hline 1 & $C$ of $G(+8)$ & 300 & 60 & $64 / 67$ & $y / y$ \\
\hline 2 & G to $A(304)$ & 244 & 53,54 & 54 & $n / y$ \\
\hline 3 & $C$ to $T(547)$ & 359 & $48 / 53 / 58$ & 58 & $n / y$ \\
\hline 3 & A to $T(488)$ & 359 & $48 / 53 / 58$ & 58 & $y / y$ \\
\hline 6 & $C$ to $T(1009)$ & 240 & 57 & 57 & $y / y$ \\
\hline 6 & G to $A(965)$ & 240 & 57 & 57 & $y / y$ \\
\hline 7 & A to $T(+2)$ & 326 & $51 / 56$ & 51 & $n / y$ \\
\hline 7 & $\mathrm{C}$ to $\mathrm{T}(+7)$ & 326 & $51 / 56$ & 51 & $n / y$ \\
\hline 7 & $C$ to $T(1216)$ & 326 & $51 / 56$ & 57 & $n / y$ \\
\hline 7 & A to $T(-2)$ & 326 & $51 / 56$ & 51 & $n / y$ \\
\hline 9 & $G$ to $C(-1)$ & 183 & 55 & 55 & $y / y$ \\
\hline 10 & $A$ to $G(+12)$ & 249 & 50,55 & $50,52,53,55$ & $y / y$ \\
\hline 10 & $C$ to $A(1632)$ & 249 & 50,55 & $50,52,53$ & $y / y$ \\
\hline 11 & T to C (1669) & 198 & 2 & 52,53 & $y / y$ \\
\hline 11 & A to g (1690) & 198 & 55 & 55 & $y / y$ \\
\hline 12 & G to C (1968) & 319 & 52,57 & 56,57 & $y / y$ \\
\hline 13 & A to $G(2157)$ & 284 & 54,59 & 54,56 & $y / y$ \\
\hline 13 & $T$ to $C(+6)$ & 284 & 54,59 & 54,56 & $y / y$ \\
\hline
\end{tabular}


Table 3. continuation

\begin{tabular}{|c|c|c|c|c|c|}
\hline \multicolumn{6}{|c|}{ Deletions } \\
\hline \multicolumn{6}{|c|}{ hMLH1 } \\
\hline 1 & $1 \mathrm{bp}(9)$ & 200 & 62 & 62 & $y / y$ \\
\hline 3 & 4 bp $(+2,208-9)$ & 181 & 55 & 55 & $y / y$ \\
\hline 7 & $1 \mathrm{bp}(588)$ & 205 & 55 & 55 & $y / y$ \\
\hline 8 & $1 \mathrm{bp}(672)$ & 149 & $48,53,58$ & 55 & $y / y$ \\
\hline 13 & $5 \mathrm{bp}(1460-1464)$ & 209 & 59 & $50,54,58,59$ & $y / y$ \\
\hline 16 & 3 bp (1846-48) & 259 & 55,60 & 53 & $y / y$ \\
\hline 17 & 2 bp (1986-1987) & 178 & 59 & $57,58,59$ & $y / y$ \\
\hline 19 & $1 \mathrm{bp}(2114)$ & 266 & 59 & 56 & $y / y$ \\
\hline \multicolumn{6}{|c|}{ hMSH2 } \\
\hline 1 & $1 \mathrm{bp}(163)$ & 300 & 60 & $64,66,67$ & $n / y$ \\
\hline 7 & $1 \mathrm{bp}(1260)$ & 326 & $51 / 56$ & 57 & $\mathrm{n} / \mathrm{y}$ \\
\hline 9 & 1 bp (1408) & 183 & 55 & $50,53,55$ & $y / y$ \\
\hline 15 & 7 bp (2502-2508) & 266 & 58 & $50,52,56$ & $y / y$ \\
\hline \multicolumn{6}{|c|}{ Insertions } \\
\hline \multicolumn{6}{|c|}{ hMLH1 } \\
\hline 12 & 4 bp (1 164) & 410 & 55,60 & $50,55,60$ & $y / y$ \\
\hline \multicolumn{6}{|c|}{ Inversions } \\
\hline \multicolumn{6}{|c|}{ hMSH2 } \\
\hline 8 & $23 \mathrm{bp}(1338-1361)$ & 212 & 53 & 53,50 & $y / y$ \\
\hline
\end{tabular}

A

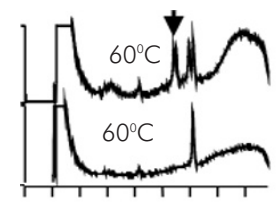

$\begin{array}{llllllll}1 & 2 & 3 & 4 & 5 & 6 & 7 & 8\end{array}$ Minutes

B

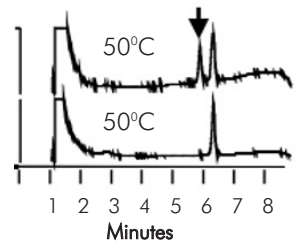

C



Fig. 1. DHPLC and DGGE detection of base substitutions, deletions, and insertions in genes associated with HNPCC. PCR products $(5 \mu \mathrm{l})$ were separated on a Helix DHPLC column under partially denaturing conditions (at the indicated temperatures) using a flow rate of 0.45 $\mathrm{ml} / \mathrm{min}$ and an increasing linear acetonitrile gradient. Arrows on DHPLC traces indicate the presence of a heteroduplex species and asterisks on DGGE gels indicate the sample represented by DHPLC analysis. (A) $116 \mathrm{G}$ to $A$ introducing a stop codon in exon 1 of $\mathrm{hMLH} 1$. (B) 1460 (del5) in exon 13 of hMLH1 (C) 1164 (ins4) in exon of $12 \mathrm{hMLH1}$



Fig. 2. Mutations and polymorphisms in the same PCR fragment distinguished by their DHPLC elution profile. PCR products $(5 \mu \mathrm{l})$ were separated on a Helix DHPLC column under partially denaturing conditions at the indicated temperature using a flow rate of $0.45 \mathrm{ml} / \mathrm{min}$ and an increasing linear acetonitrile gradient. Arrows on DHPLC traces indicate the presence of heteroduplex species. The polymorphism is a $655 \mathrm{G}$ to $\mathrm{A}$ substitution and the mutation a 672 delT, both in exon 8 of the hMLH1 gene. (A) sample homozygous for the polymorphism and heterozygous for the mutation. (B) sample heterozygous for both the polymorphism and the mutation; (C) sample homozygous for both the polymorphism and mutation; (D) sample heterozygous for the polymorphism and homozygous for the mutation; (E) same as $D$ separated at $58^{\circ} \mathrm{C}$ 
Table 4. Relative percentage of mutations identified by DGGE or DHPLC

\begin{tabular}{lccc}
\hline Method & Number identified & Number not identified & Total \\
\hline DGGE & $41(82 \%)$ & $9(18 \%)$ & 50 \\
\hline DHPLC & $50(100 \%)$ & $0(0 \%)$ & 50 \\
\hline
\end{tabular}

A

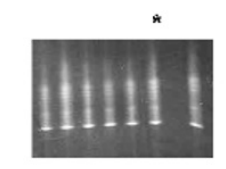

B

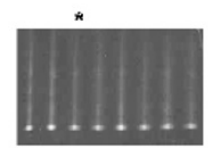

C

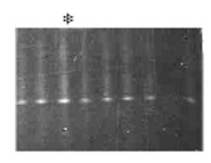


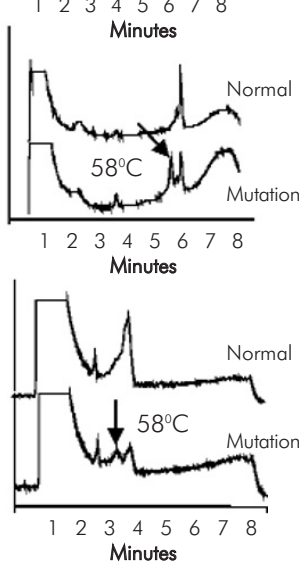

Fig. 3. Mutations undetected by DGGE that were detected by DHPLC. PCR products $(5 \mu \mathrm{l})$ were separated on a Helix column at the indicated temperature and a $0.45 \mathrm{ml} / \mathrm{min}$ flow rate. A linear increasing acetonitrile gradient was used to elute the DNA from the column. Arrows indicate the presence of heteroduplex species on DHPLC traces for (A) hMLH1 exon 6,544 +51 T to C; (B) hMSH2 exon $13,1558+6 \mathrm{~T}$ to $\mathrm{C}$ and $(\mathrm{C}) \mathrm{hMLH1}$ exon $10,884 \mathrm{G}$ to $\mathrm{A}$



Fig. 4. Predictive ability of DHPLC profiles. Identical profiles were observed at the predicted oven temperature for both a $1009 \mathrm{C}>\mathrm{T}$ substitution (A) and a $965 \mathrm{G}$ to $A$ substitution (B) in exon 6 of the hMSH2 gene. These profiles were different to those obtained for a $984 \mathrm{C}$ to $\mathrm{T}$ substitution (C) and no substitutions (D) in the same fragment. PCR products $(5 \mu \mathrm{l})$ were separated on a Helix DHPLC column under partially denaturing conditions using a flow rate of $0.45 \mathrm{ml} / \mathrm{min}$ and an increasing linear acetonitrile gradient. make this analytical procedure more expensive than DHPLC. Of particular note is the speed of genetic screening by DHPLC, which is far superior to DGGE and indeed, DNA sequencing, when used as a screening tool. The most expensive consumable cost is replacement of the column, which should be used according to the manufacturers' instructions to maximize column life. So long as this number of injections can be assured from the column the cost effective advantage of DHPLC is much greater than DGGE.

The use of DHPLC analysis for the identification of mutations represents a significant move forward in the diagnosis of HNPCC. There are, however, aspects of DHPLC analysis that require attention prior to this approach being accepted as a standard laboratory procedure. A potential limitation of this technique is the variability in column life, which may be a function of temperature particularly if the columns are continuously used at a temperature greater than $60^{\circ} \mathrm{C}$ (Varian Inc., Melbourne, personal communication).

The DNA denaturing temperature estimates generated from the DHPLC-MELT algorithm predicted DNA melting temperatures relatively accurately for single base changes and single base pair insertions and deletions. Larger deletions (over 3 base pairs) or complex changes are also easily identified with careful selection of column temperature.

In summary, DHPLC represents a cost-effective and rapid approach to the identification of genetic changes in HNPCC. DHPLC technology accelerates mutation analysis with improvements in sensitivity and specificity resulting in a more cost-effective approach to mutation detection.

\section{References}

1. Lynch HT, Lanspa S, Smyrk T, Boman, B, Watson P, Lynch J. Hereditary nonpolyposis colorectal cancer (Lynch Syndromes I \& II). Genetics, pathology, natural history, and cancer control, part I. Cancer Genet Cytogenet 1991 ; 53: 143-150.

2. Watson P, Lynch HT. Extracolonic cancer in hereditary non polyposis colorectal cancer. Cancer 1993; 71: 677-685.

3. Katballe N, Christensen M, Wikman FP, Orntoft TF, Laurberg S. Frequency of hereditary non-polyposis colorectal cancer in Danish colorectal cancer patients. Gut 2002; 50: 43-51.

4. Samowitz WS, Curtin K, Lin HH, Robertson MA, Schaffer D, Nichols M, Gruenthal K, Leppert MF, Slatery ML. The colon cancer burden of genetically defined hereditary nonpolyposis colon cancer. Gastroenterology 2001; 121: 1005-1008. 
5. Fishel R, Lescoe MK, Rao MRS, Copeland NG, Jenkins NA, Garber J, Kane M, Kolodner R. The human mutator gene homolog $\mathrm{MSH} 2$ and its association with hereditary nonpolyposis colon cancer. Cell 1993; 75: 1027-1038.

6. Leach FS, Nicolaides NC, Papadopoulos N, Liu B, Jen J, Parsons R, Peltomaki P, Sistonen P, Aaltonen LA, Nystran-Lahti M, Guan XY, Zhang J, Meltzer PS, Yu J-W, Kao F-T, Chen DJ, Cerosaletti KM, Fournier REK, Todd S, Lewis T, Leach RJ, Naylor SL, Weissenbach J, Mecklin J-P, Jarvinen H, Petersen GM, Hamilton SR, Green J, Jass J, Watson P, Lynch HT, Trent JM, de la Chapelle A, Kinzler $\mathrm{KW}$, Vogelstein B. Mutations in a mutS homolog in hereditary nonpolyposis colorectal cancer. Cell 1993; 75: 1215-1225.

7. Bronner CE, Baker SM, Morrison PT, Warren G, Smith LG, Lescoe MK, Kane M, Earabino C, Lipford J, Lindblom A, Tannergard P, Bollag RJ, Godwin AR, Ward DC, Nordenskiold M, Fishel R, Kolodner R, Liskay RM. Mutation in the DNA mismatch repair gene homologue hMLH1 is associated with hereditary nonpolyposis colon cancer. Nature 1994; 368: 258-261.

8. Nicolaides NC, Papadopoulos N, Liu B, Wei Y-F, Carter KC, Ruben SM, Rosen CA, Haseltine WA, Fleischmann RD, Fraser GM, Adams MD, Venter JC, Dunlop MG, Hamilton SR, Petersen GM, de la Chapelle A, Vogelstein B, Kinzler K. Mutations of two PMS homologues in hereditary nonpolyposis colon cancer. Nature 1994; 371 : 75-80.

9. Liu B, Nicolaides NC, Markowitz S, Willson JK, Parsons RE, Jen J, Papadopoulos N, Peltomaki P de la Chapelle A, Hamilton SR, Kinzler KW, Vogelstein B. Mismatch repair gene defects in sporadic colorectal cancers with microsatellite instability. Nature Genet 1995; 9: 48-55.

10. Papadopoulos N, Lindblom A. Molecular basis of HNPCC: mutations of MMR genes. Hum Mutat 1997; 10: 89-99

11. Ionov Y, Peinado MA, Malkhosyan S, Shibata D, Perucho M. Ubiquitous somatic mutations in simple repeated sequences reveal a new mechanism for colonic carcinogenesis. Nature 1993; 363: 558-561.

12. Thibodeau SN, Bren G, Schaid D. Microsatellite instability in cancer of the proximal colon. Science 1993; 260: 816-819.

13. Buerstedde JM, Alday P, Torhorst J, Weber W, Muller H, Scott R. Detection of new mutations in six out of 10 Swiss HNPCC families by genomic sequencing of the hMSH2 and hMLH1 genes. J Med Genet 1995; 32: 909-912.

14. Wijnen JT, Vasen HFA, Meera Khan P, Zwindermann AH, van der Klift H, Mulder A, Tops C, Moller P, Fodde R. Clinical findings with implications for genetic testing in families with clustering of colorectal cancer. New Engl J Med 1998; 339: 511 -518.

15. Heinimann K, Scott RJ, Buerstedde J-M, Weber W, Siebold K, Attenhofer M, Mueller Hi, Dobbie Z. Influence of selection criteria on mutation detection in patients with hereditary nonpolyposis colorectal cancer. Cancer 1999; 86: 2512-2518.

16. Syngal S, Fox EA, Li C, Dovidio M, Eng C, Kolodner RD, Garber JE. Interpretation of genetic test results for hereditary nonpolyposis colorectal cancer. Implications for clinical predisposition testing. JAMA 1999; 282: 247-253.

17. Wahlberg S, Liu T, Lindblom P, Lindblom A. Various mutation screening techniques in the DNA mismatch repair genes hMSH2 and hMLH1. Genetic Testing 1999; 3: 259-264.

18. Oefner PJ. Allelic discrimination by denaturing high-performance liquid chromatography. J Chromatogr B Biomed Sci Appl 2000; 739: 345-355.

19. Eng C, Brody LC, Wagner TMU, Devilee P, Viig J, Czabo C, Tavtigian SV, Nathanson KL, Ostrander E, Frank TS and the Steering committee of the Breast Cancer Information Core (BIC) consortium. Interpreting epidemiological research: blinded comparison of methods used to estimate the prevalence of inherited mutations in BRCA1. J Med Genet 2001; 38: 824-833.

20. Scott RJ, McPhillips M, Meldrum CJ, Fitzgerald PE, Adams, K, Spigelman AD, du Sart D, Tucker K, Kirk J, and the Hunter Family Cancer Service. Hereditary non polyposis colorectal cancer in 95 families: Differences and similarities between mutation positive and mutation-negative kindreds. Am J Hum Genet 2001; 68: 118-127.1. 1.

21. Vasen HF, Mecklin JP, Khan PM, Lynch HT. The International Collaborative Group on Hereditary Non-Polyposis Colorectal Cancer (ICG-HNPCC). Dis Colon Rectum 1991; 34: 424-425.

22. Miller SA, Dykes DD, Polesky $H$. A simple salting out procedure for extracting DNA from human nucleated cells. Nucleic Acids Res 1988; 53: 739.

23. Wijnen J, Vasen $H$, Meera Khan P, Menko FH, van der Klift H, van Leeuwen $C$, van den Broek $M$, van Leeuwen-Cornelisse I, Nagengast F, Meijers-Heijboer A, Lindhout D, Griffioen G, Cats A, Kleibeuker J, Varesco L, Bertario L, Bisgaard ML, Mohr J, Fodde R. Seven new mutations in hMSH2, an HNPCC gene, identified by denaturing gradient gel electrophoresis. Am J Hum Genet 1995; 56: 1060-1066.

24. Wijnen J, Meera Khan P, Vasen H, Menko FH, van der Klift H, van der Broek M, van Leeuwen-Cornelisse I, Nagengast $F$, Meijers-Heijboer EJ, Lindhout D, Griffioen G, Cats A, Kleibeuker J, Varesco L, Bertario L, Bisgaard ML, Mohr J, Kolodner R, Fodde R. Majority of hMLH1 mutations responsible for hereditary nonpolyposis colorectal cancer (HNPCC) cluster at the exonic region 15-16. Am J Hum Genet 1996; 58: 300-307.

25. Ziao W, Oefner PJ. Denaturing high performance liquid chromatography: A review. Hum Mutat 2001; 17: 439-474.

26. Lerman LS and Silverstein K. Computational analysis of DNA melting and its application to denaturing gradient gel electrophoresis. In Wu R, Grossman L (eds) Methods in enzymology. Vol 155. Academic Press, New York 1987; pp 482-501.

27. Kolodner RD, Hall NR, Lipford J, Kane MF, Rao MR, Morrison P, Wirth L, Finan PJ, Burn J, Chapman P. Structure of human MSH2 locus and analysis of two Muire-Torre kindreds for msh2 mutations. Genomics 1994; 24: 516-526.

28. Liu B, Parsons RE, Hamilton SR, Petersen GM, Lynch HT, Watson P, Markowitz, S, Willson JK, Green J, de la Chapelle A. Kinzler $\mathrm{KW}$, Vogelstein B. hMSH2 mutations in hereditary non-polyposis colorectal cancer kindreds. Cancer Research 1994; 54: 45904594. 